\title{
GENETIC VARIABILITY, ASSOCIATION AND DIVERSITY ANALYSIS IN UPLAND RICE (Oryza sativa L)
}

\author{
R. Khare, A. K. Singh, S. Eram and P. K. Singh * \\ Department of Genetics and Plant Breeding, Institute of Agricultural Sciences, \\ Banaras Hindu University, Varanasi-221005, India
}

\begin{abstract}
High heritability coupled with high to moderate phenotypic and genotypic coefficient of variation and genetic advance as per cent of mean was recorded for grain yield per plant, plant height, test weight, fertile spikelet per panicle, total grains per panicle and number of effective tillers per plant. Positive and significant association were observed for days to 50 per cent flowering, days to maturity, plant height, panicle length, fertile spikelet per panicle, total grains per panicle and spikelet fertility with grain yield per plant at both genotypic and phenotypic level, while highest positive direct effect on grain yield was recorded by fertile spikelet per panicle, total number of grains per panicle, plant height and days to $50 \%$ flowering. Based on ten quantitative traits the accessions were clustered into seven groups, the cluster III contained highest 14 accessions, followed by clusters I comprised 11 accessions and cluster VI, VII, V, IV and II have 9, 8, 7, 6 and 5 accessions, respectively. The first four principal components accounted for $77.13 \%$ of total variation of all the traits.
\end{abstract}

Key words: Correlation, Path analysis, Variability and Upland rice.

\section{INTRODUCTION}

Rice (Oryza sativa L.) is a highly domesticated crop, and domestication processes are reported to be accompanied by genetic erosion, which causes a reduction in genetic diversity among traditional varieties and gradual loss of landraces from the fields (Brush, 2000). Modern rice cultivars have been developed through the hybridization of elite lines and subsequent selection for yield and quality traits. The genetic potential and magnitude of heterogeneity are still present in local landraces need to characterize in available upland rice germplasm.

Grain yield is dependent on many yield contributing traits as well as on the environmental influence. Genetic variability of yield contributing traits and

* Corresponding author email: pksbhu@gmail.com

Received: 21.04.2014 
interrelationship among them and their relation with yield are necessary for a successful breeding program. Knowledge of heritability is essential for selection based improvement. Before placing strong emphasis on breeding for yield improvement trait, the knowledge on the association between yield and yield attributes will immense help the breeder in the improvement of yield. The correlation coefficient may also help to identify characters that have little or no importance in the selection programme. The existence of correlation may be attributed to the presence of linkage or pleiotropic effect of genes or physiological and development relationship or environmental effect or in combination of all (Oad et al., 2002). Path coefficient analysis proposed by Wright (1921) help the partition the total correlation into direct and indirect effects of various causes. The spectrum of variability in segregating generation for grain yield traits depends on the genetic diversity of the combining parents. Hence, estimation of genetic diversity for yield traits among accessions is important for planning the future crossing programmes. Thus, the present investigation was undertaken to assess the genetic variability, association among the traits, their path coefficient and diversity analysis for grain yield and other traits.

\section{MATERIALS AND METHODS}

Panicles of sixty upland rice germplasm accessions were collected from natural habitat of Eastern India and DBT Networking Project, Institute of Agricultural Sciences, Banaras Hindu University, Varanasi during wet 2008-09 and their seeds were multiplied during next wet season 2010. The accessions were evaluated in randomized block design with three replications during kharif 2011 and 2012. Twenty days old single seedlings were transplanted with a spacing of $20 \times 15 \mathrm{~cm}$ in $3.0 \times 1.5 \mathrm{~m}$ plot. The recommended packages of practices were followed to raise a healthy crop. Where are fertilizer dosages? The source of upland rice germplasm accessions are presented in table 1.

The observations were recorded on days to $50 \%$ flowering, days to maturity, plant height, panicle length, effective tillers per plant, fertile spikelet per panicle, total number of grains per panicle, spikelet fertility percentage, test weight and grain yield per plant. Randomly ten plants are selected from each replication in each germplasm excluding border rows. Ten randomly selected plants in each accession in each replication were tagged for recording observation. The panicles of accessions showing shattering characteristics were observed daily and fertile spikelets were plucked one by one before shattering and stored.

The mean value of both years were pooled over and used for statistical analysis. The data was analyzed for variability as per procedure given by Panse and Sukhatme (1985). The genotypic and phenotypic coefficients of variability were worked out as per Burton and De-Vane (1953); heritability and genetic advance were estimated as per formula given by Allard (1960). Estimates of correlation coefficient 
were worked as per Al-Jibouri et al. (1958) and path analysis given by Dewey and Lu (1959). Cluster and principle component analysis (PCA) were carried out by using SPSS 16.0 version software.

\section{RESULTS AND DISCUSSION}

\section{Variation and genetic parameters among accessions}

The analysis of variance revealed highly significant difference among the germplasm accessions for all the traits indicating a large amount of variability was present in the set of material for effective selection (Table 2). The magnitude of phenotypic coefficient of variations was higher for yield and yield attributing traits but the difference is very less indicates the presence of environmental influence to some degree in the phenotypic expression of the traits (Table 3). Similar results were reported by Subudhi et al. (2011). The highest estimate of PCV and GCV were observed for fertile spikelet per panicle, total grains per panicle, grain yield per plant and number of effective tillers per plant, while the lowest in days to maturity and days to 50 per cent flowering. Similarly, Bhadru et al, (2012) reported high PCV and GCV for number of grains per panicle, fertility percentage and grain yield per plant in rice. The estimate of heritability were high for test weight $(98.30 \%)$, plant height $(97.83 \%)$, grain yield per plant $(96.52 \%)$, days to 50 per cent flowering $(94.50 \%)$ and days to maturity $(93.94 \%)$ due to genetic causes rather only by environmental effects. High heritability does not always indicate high genetic gain; heritability coupled with high genetic advance should be used in predicting the ultimate effect for selecting superior varieties. High heritability along with high genetic advance as per cent of mean was recorded for grain yield per plant, fertile spikelet per panicle, total number of grains per panicle, plant height and number of effective tillers per plant indicated that the less influence of environmental effect in the inheritance of these traits. High heritability coupled with low genetic advance as per cent mean were observed in days to maturity and days to $50 \%$ flowering. Similar results were also reported by Pratap et al. (2012) and Gangashetty et al. (2013).

\section{Character association and path analysis}

The estimates of phenotypic and genotypic correlation coefficient are presented in table 4. The genotypic correlation coefficient was found to be higher than phenotypic correlation coefficient except for days to maturity indicating a strong inherent association for grain yield per plant and other traits also. Days to 50 per cent flowering, days to maturity, plant height, panicle length, fertile spikelet per panicle, total grains per panicle and spikelet fertility showed strong positive and significant association with grain yield per plant both at genotypic and phenotypic levels. The association studied indicating grain yield of rice can be improved by selecting germplasm having higher performances for these traits. These results are in conformity with findings of Singh et al. (2013a). The grain yield per plant had a negative significant association with test weight, while negative non-significant with 
number of effective tillers per plant. The result of path coefficient analysis between yield and yield related traits showed that, the traits via fertile spikelet per panicle, days to maturity, number of effective tillers per plant and plant height exhibited direct positive effect on grain yield. The strong positive association of fertile spikelet per panicle with grain yield was mainly observed through its direct effect, whereas total grains per panicle through its indirect effect of fertile spikelet per panicle (Table 5). Kumar and Saravanan (2012) and Minnie et al. (2013) reported similar results for days to maturity, number of productive tillers per plant, panicle length, fertile spikelet per panicle and spikelet fertility.

\section{Cluster and principal component analysis}

Rice accessions collected for the study were statistically analyzed for similarities in their quantitative traits using cluster observations analysis by Ward method. The accessions were partitioned into seven clusters based on similarities in characteristics (Figure 1). The cluster III contained the highest 14 accessions followed by clusters I and VI comprised 11 and 9 accessions. Cluster VII contained 8 accessions, while cluster V, IV and II have 7, 6 and 5 accessions, respectively. The clustering pattern indicates wide diversity between different groups of accessions. Accessions falling in a particular cluster indicate their close relationship among themselves as compared to the other clusters. Therefore, it could be expected that accessions within a cluster were less genetically different with each other, and were diverse from the cultivars belonging to other clusters. These finding are conformity with the results of Singh et al. (2012) and Singh et al. (2013b). The genetic distance between the parents largely governs the variability spectrum generated in the segregating generation. Therefore, diverse accessions could be used in breeding programme for improvement of quality traits.

Principal component analysis was further used to establish the patterns and interrelationships existing between the accessions and their quantitative traits. The first four principal components explained a total of $77.13 \%$ of the total variability in the all qualitative traits. The analysis of eigenvectors gave the information of qualitative traits for percentage of variation to the first four principal components, which were $39.20,15.41,12.11$ and $10.41 \%$, respectively (Table 6). Similarly, Singh et al. (2013b) reported the first three principal components accounting for $62.72 \%$ of total variation among thirty five wild rice germplasm.

\section{CONCLUSION}

The accessions were clustered into seven clusters. The cluster I could be hybridized with cluster VI and VII to achieve a wide spectrum of variation among the segregates. Principal component analysis indicated $77.13 \%$ of the total variation showed by first four principal components. PCA and cluster analysis complemented each other with some slight inconsistencies in terms of cluster composition. The separation and selection of varieties based on high heritability along with high 
genetic advance of traits make it easy for breeders to exploit their knowledge and skill in transgressive segregation breeding programme. In this experiment, grain yield per plant, plant height, test weight, fertile spikelet per panicle, total grains per panicle and number of effective tillers per plant had high heritability with high genetic advance, while traits days to maturity, plant height and fertile spikelet per panicle positive direct effect and significant association with grain yield per plant at phenotypic and genotypic levels. Therefore, selections of diverse accessions combine with desirable traits are to be effective in accumulation of favourable genes for bringing together into the common genetic background of cultivated indica rice Oryza sativa L.

\section{ACKNOWLEDGEMENT}

Authors are thankful to U.P. Council of Agricultural Research, Lucknow U.P., India for financial support (P-26/75).

\section{REFERENCES}

Al-Jibouri, H. A., Miller, P.A. and Robinson, H.F. 1958. Genotypic and environmental variations and covariance in upland cotton cross of interspecific origin. Agronomy Journal, 50: 633-36

Allard, R.W. 1960. Principles of Plant Breeding. John Wiley and Sons, Inc. New York, p. 485

Bhadru, D., Rao, V. Tirumala, Mohan, Y. Chandra and Bharathi, D. 2012. Genetic variability and diversity studies in yield and its component traits in rice (Oryza sativa L.). SABRAO Journal of Breeding and Genetics, 44(1): 129-137

Brush S.B. 2000. The Issues of in Situ Conservation of Crop Genetic Resources. In: Genes in the Field: On-Farm Conservation of Crop Diversity (Brush SB, ed.). IPGRI, IDRC

Burton, G.W. and De-Vane, E.H. 1953. Estimating heritability in tall fescue Festuca arundinaceae from replicated clonal material. Agronomy Journal, 45: 578-581

Dewey, D.R. and Lu, K.H. 1959. A correlation and path coefficient analysis of components of crested wheat grass seed production. Agronomy Journal, 51: 515-18

Gangashetty, P., Salimath, P. and Hanamaratti, N. 2013. Genetic variability studies in genetically diverse non-basmati local Aromatic genotypes of rice (Oryza sativa $\mathrm{L}$ ). Rice Genomics and Genetics, 4(2): 4-8

Kumar, P.S. and Saravanan, K. 2012. Genetic variability, correlation and path analysis in rice (Oryza Sativa L.). International Journal of Current Research, 4(9): 082-085

Minnie, C.M., Reddy, T.D. and Raju, C.S. 2013. Correlation and path analysis for yield and its components traits (Oryza sativa L.). Journal of Research ANGRAU, 41(1): 132-134

Oad, F.C., Samo, M.A., Hassan, Z.U., Pompe, S.C. and Oad, N.L. 2002. Correlation and path analysis of quantitative characters of rice ratoon cultivars and advance lines. International journal of Agricultural and Biology, 4(2): 204-207

Panse, V.G. and Sukhatme, P.V. 1985. Statical methods for Agricultural workers. $4^{\text {th }}$ edition ICAR, New Delhi 
Pratap, N., Singh, P.K., Shekhar, R., Soni S.K. and Mall A.K. 2012. Genetic variability, character association and diversity analyses for economic traits in rice (oryza sativa L.). SAARC Journal of Agriculture, 10(2): 83-94

Singh, A., Singh, A.K., Parveen, S. and Singh, P.K. 2013a. Studies on genetic characteristic of upland rice (Oryza sativa L.). International Journal of Agriculture, Environment and Biotechnology, 6(4): 515-520

Singh, A., Singh, B., Panda, K., Rai, V.P., Singh, A.K., Singh, S.P., Chouhan, S.K., Rai, V., Singh, P.K. and Singh, N.K. 2013b. Wild rice of Eastern Indo-Gangetic plains of India constitutes two sub-populations harbouring rich genetic diversity, Plant Omics Journal, 6(2): 121-127

Singh, Praveen, Pandey, Anil, Mishra S.B. and Kumar, Rajesh 2012. Genetic divergence study in aromatic rice (Oryza sativa L.), SABRAO Journal of Breeding and Genetics, 44(2): 356-369

Subudhi, H.N., Das, S., Swain, D. and Singh, O.N. 2011. Variability, correlation and path analysis for quality characters in rice. Oryza, 48(4): 319-323

Wright, S. 1921. Systems of mating. Genetics, 6: 111-178 


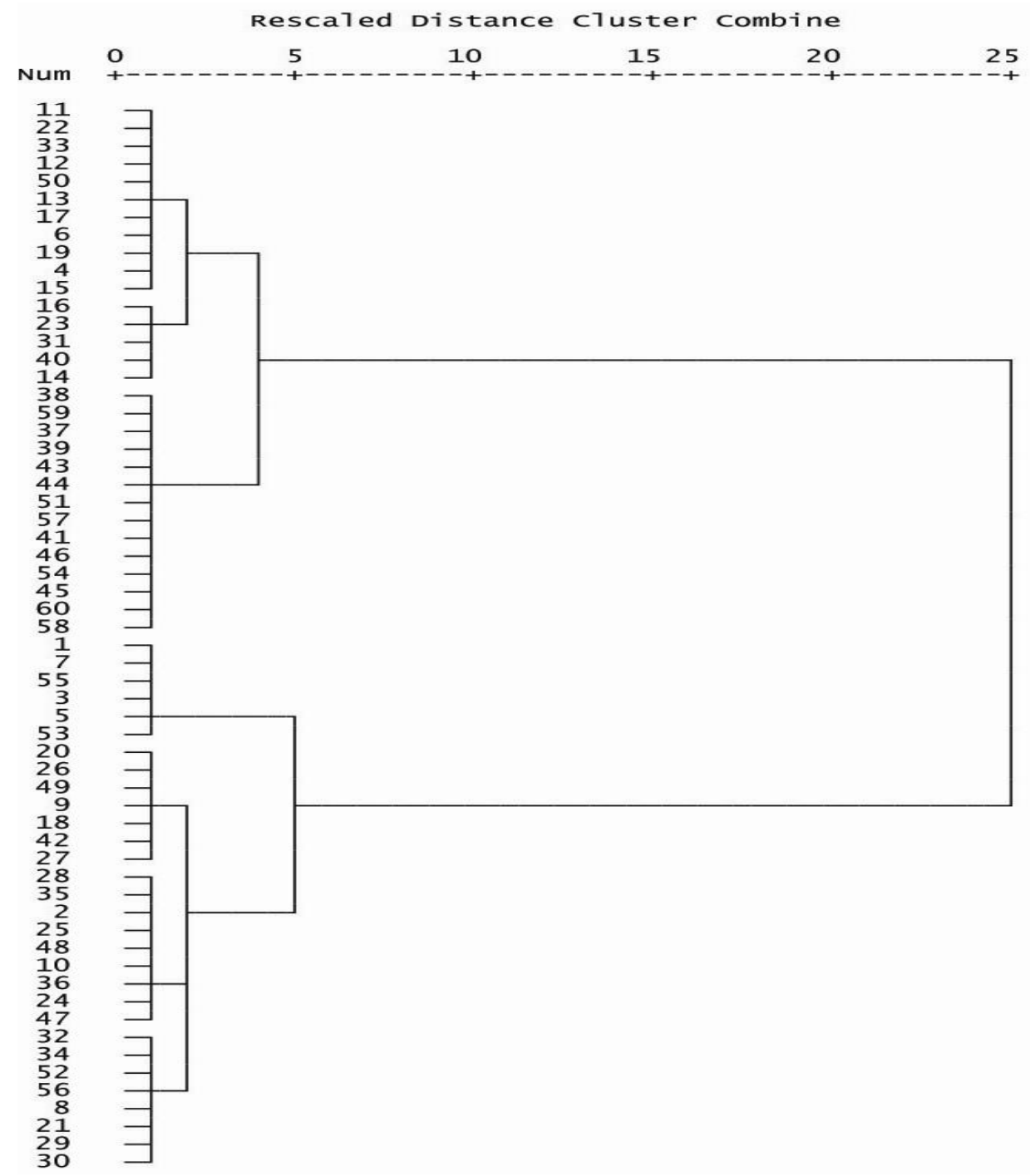

Figure1: Dendrogram showing clusters of 60 upland rice germplasm accessions formed by Ward method and numbers 1-60 represent rice germplasm accessions as described in table 1. 
Table 1: List of sixty upland rice germplasm accessions and their collection site

\begin{tabular}{|c|c|c|}
\hline S.N. & Accession Number & Collection site (Village, Block, District, Country)/Source \\
\hline 1 & PKSLGR-1 & Hingutarghar, Dhanapur, Chandauli, India \\
\hline 2 & PKSLGR-2 & Nakenampur, Dhanapur, Chandauli, India \\
\hline 3 & PKSLGR-3 & Bhaluadai, Shahabganj, Chandauli, India \\
\hline 4 & PKSLGR-4 & Bishunpura, Chakiya, Chandauli, India \\
\hline 5 & PKSLGR-5 & Mamarakpur, Shahabganj, Chandauli, India \\
\hline 6 & PKSLGR-6 & Ramghar, Chakiya, Chandauli, India \\
\hline 7 & PKSLGR-7 & Muzafferpur, Chakiya, Chandauli, India \\
\hline 8 & PKSLGR-8 & Diberiya, Chakiya, Chandauli, India \\
\hline 9 & PKSLGR-9 & Nawajganj, Chakiya, Chandauli, India \\
\hline 10 & PKSLGR-10 & Ghorawal, Newarpura, Sonbhadra, India \\
\hline 11 & PKSLGR-11 & Dumahar, Babhani, Sonbhadra, India \\
\hline 12 & PKSLGR-12 & Dadvahani, Babhani, Sonbhadra, India \\
\hline 13 & PKSLGR-13 & Satvahani, Babhani, Sonbhadra, India \\
\hline 14 & PKSLGR-14 & Chhiyari, Babhani, Sonbhadra, India \\
\hline 15 & PKSLGR-15 & Mahuariya, Babhani, Sonbhadra, India \\
\hline 16 & PKSLGR-16 & Nibi, Vijaypur, Mirzapur, India \\
\hline 17 & PKSLGR-17 & Tilai, Vijaypur, Mirzapur, India \\
\hline 18 & PKSLGR-18 & Joya, Vijaypur, Mirzapur, India \\
\hline 19 & PKSLGR-19 & Tamua, Madiyan, Mirzapur, India \\
\hline 20 & PKSLGR-20 & Katariya, Madiyan, Mirzapur, India \\
\hline 21 & PKSLGR-21 & Barakachha, Madiyan, Mirzapur, India \\
\hline 22 & PKSLGR-22 & Gulalpur, Madiyan, Mirzapur, India \\
\hline 23 & PKSLGR-23 & Dhanawal, Madiyan, Mirzapur, India \\
\hline 24 & PKSLGR-24 & Ninwar, Lalganj, Mirzapur, India \\
\hline 25 & PKSLGR-25 & Sikhar, Sikhar, Mirzapur, India \\
\hline 26 & PKSLGR-26 & Baburi, Vijaypur, MirzapurI, India \\
\hline 27 & PKSLGR-27 & Shisotar, Nawanagar, Ballia, India \\
\hline 28 & PKSLGR-28 & Maturi, FatehpurManda, Ballia, India \\
\hline 29 & PKSLGR-29 & Deorara, Bansdih, Ballia, India \\
\hline 30 & PKSLGR-30 & Mehnagar, Meghnaghar, Ajamghar, India \\
\hline 31 & PKSLGR-31 & Naretha, Jahanaganj, Azamgarh, India \\
\hline 32 & PKSLGR-32 & Shahpur, Jahanaganj, Azamgarh, India \\
\hline
\end{tabular}




\begin{tabular}{c|l|l}
\hline S.N. & Accession Number & Collection site (Village, Block, District, Country)/Source \\
\hline 33 & PKSLGR-33 & Kotila, Rani Kisarai, Azamgarh, India \\
34 & PKSLGR-34 & Mehnagar, Meghnaghar, Ajamghar, India \\
35 & PKSLGR-35 & Naretha, Jahanaganj, Azamgarh, India \\
36 & PKSLGR-36 & Shahpur, Jahanaganj, Azamgarh, India \\
37 & PKSLGR-37 & Kotila, Rani Kisarai, Azamgarh, India \\
38 & PKSLGR-38 & Ganjari Dheeh, Gangapur, Varanasi, India \\
39 & PKSLGR-39 & Raghunathpur, Sewapuri, Varanasi, India \\
40 & PKSLGR-40 & Bhainsa, Sewapuri, Varanasi, India \\
41 & IC346813 & DBT, New Delhi, India \\
42 & IC346880 & DBT, New Delhi, India \\
43 & IC356117 & DBT, New Delhi, India \\
44 & IC356422 & DBT, New Delhi, India \\
45 & IC356429 & DBT, New Delhi, India \\
46 & IC356431 & DBT, New Delhi, India \\
47 & IC356432 & DBT, New Delhi, India \\
48 & IC362206 & DBT, New Delhi, India \\
49 & IC383441 & DBT, New Delhi, India \\
50 & IC383559 & DBT, New Delhi, India \\
51 & IC391524 & DBT, New Delhi, India \\
52 & IC418382 & DBT, New Delhi, India \\
53 & IC426012 & DBT, New Delhi, India \\
54 & IC426017 & DBT, New Delhi, India \\
55 & IC426058 & DBT, New Delhi, India \\
56 & IC426061 & DBT, New Delhi, India \\
57 & IC426137 & DBT, New Delhi, India \\
58 & IC438644 & DBT, New Delhi, India \\
59 & EC545051 & DBT, New Delhi, India \\
60 & EC545061 & DBT, New Delhi, India \\
\hline & &
\end{tabular}


Table 2: Analysis of variance for ten quantitative traits in sixty upland rice germplasm

\begin{tabular}{|c|c|c|c|c|c|c|c|c|c|c|c|}
\hline \multirow{2}{*}{$\begin{array}{l}\text { Source of } \\
\text { variation }\end{array}$} & \multirow[t]{2}{*}{ Df } & \multicolumn{10}{|c|}{ Mean sum of squares } \\
\hline & & DF & DM & PH & PL & ET & FSP & TGP & SF \% & TW & GYP \\
\hline 'eplication & 2 & 4.87 & 6.16 & 16.70 & 0.21 & 1.84 & 30.58 & 338.07 & 50.18 & 0.90 & 0.89 \\
\hline 'reatment & 59 & $\begin{array}{l}130.04 \\
* *\end{array}$ & $\begin{array}{l}159.87 \\
* *\end{array}$ & $\begin{array}{l}1266.42 \\
* *\end{array}$ & $\begin{array}{l}23.26^{*} \\
*\end{array}$ & $\begin{array}{l}10.75 \\
* *\end{array}$ & $\begin{array}{l}4218.73 \\
* *\end{array}$ & $\begin{array}{c}1696.65 * \\
*\end{array}$ & $\begin{array}{c}174.49 * \\
*\end{array}$ & $\begin{array}{c}32.97 * \\
*\end{array}$ & $12.84 * *$ \\
\hline Error & 118 & 2.47 & 3.36 & 9.30 & 1.45 & 1.10 & 227.49 & 296.43 & 30.99 & 0.189 & 0.86 \\
\hline
\end{tabular}

**Significant at $1 \%$ level of significance.

$\mathrm{DF}=$ Days to $50 \%$ flowering, $\mathrm{DM}=$ Days to maturity, $\mathrm{PH}=$ Plant height, $\mathrm{PL}=$ Panicle length, $\mathrm{ET}=$ Number of effective tillers per plant, $\mathrm{FSP}=$ Fertile spikelet per panicle, $\mathrm{TGP}=$ Total number of grains per panicle, SF\%= Spikelet fertility, TW= Test weight and GYP= Grain yield per plant.

Table 3: Variability parameters for ten quantitative traits in sixty upland rice germplasm.

\begin{tabular}{lccc|c|c|c|c|c|c|c|c|c}
\hline TraitsParameter & & DF & DM & PH & PL & ET & FSP & TGP & SF\% & TW & GYP \\
\hline Range & Min. & 74 & 94.33 & 82.47 & 15.53 & 3.89 & 46.5 & 52.6 & 61.67 & 12.07 & 8.45 \\
& Max. & 106.66 & 130.67 & 158.95 & 30.24 & 12.33 & 190.07 & 210.8 & 96.20 & 28.14 & 27.83 \\
Grand mean & & 85.38 & 113.81 & 111.79 & 24.05 & 7.56 & 108.19 & 122.21 & 87.96 & 21.11 & 16.65 \\
SE of mean ( \pm ) & & 0.91 & 1.05 & 1.75 & 0.69 & 0.60 & 8.64 & 9.94 & 3.21 & 0.25 & 0.54 \\
Phenotypic variance & & 44.99 & 55.54 & 428.34 & 8.72 & 4.32 & 1557.90 & 1763.17 & 78.82 & 11.12 & 24.86 \\
Genotypic variance & & 42.52 & 52.17 & 419.04 & 7.27 & 3.22 & 1330.41 & 1466.74 & 47.83 & 10.93 & 23.99 \\
Variability (\%) & PCV & 7.86 & 6.55 & 18.51 & 12.28 & 27.47 & 36.48 & 34.36 & 10.09 & 15.79 & 29.94 \\
& GCV & 7.64 & 6.35 & 18.31 & 11.21 & 23.72 & 33.71 & 31.34 & 7.86 & 15.66 & 29.71 \\
& ECV & 1.84 & 1.61 & 2.73 & 5.02 & 13.87 & 13.94 & 14.09 & 6.33 & 2.06 & 5.58 \\
& & 94.50 & 93.94 & 97.83 & 83.32 & 74.52 & 85.40 & 83.19 & 60.89 & 98.30 & 96.52 \\
$\begin{array}{l}\text { Heritability (Broad } \\
\text { sense) (\%) }\end{array}$ & & & & & & & & & & & \\
$\begin{array}{l}\text { Genetic advance as \% } \\
\text { of mean }\end{array}$ & 15.29 & 12.67 & 37.31 & 21.08 & 42.18 & 64.18 & 58.88 & 12.62 & 31.98 & 59.52 \\
\hline
\end{tabular}

$\mathrm{DF}=$ Days to $50 \%$ flowering, $\mathrm{DM}=$ Days to maturity, $\mathrm{PH}=\mathrm{Plant}$ height, $\mathrm{PL}=$ Panicle length, $\mathrm{ET}=$ Number of effective tillers per plant, $\mathrm{FSP}=$ Fertile spikelet per panicle, $\mathrm{TGP}=$ Total number of grains per panicle, $\mathrm{SF} \%=$ Spikelet fertility, $\mathrm{TW}=$ Test weight and $\mathrm{GYP}=$ Grain yield per plant. 
Table 4: Phenotypic $\left(\mathbf{r}^{\mathrm{ph}}\right)$ and genotypic $\left(\mathrm{r}^{\mathrm{g}}\right)$ correlation coefficients among ten traits in sixty upland rice germplasm

\begin{tabular}{|c|c|c|c|c|c|c|c|c|c|c|}
\hline \multicolumn{2}{|c|}{ Traits } & DM & PH & PL & ET & FSP & TGP & SF\% & TW & GYP \\
\hline \multirow[t]{2}{*}{ DF } & $\mathrm{r}^{\mathrm{ph}}$ & $0.800^{* *}$ & $0.172 *$ & $0.280 * *$ & $-0.149 *$ & $0.441 * *$ & $0.474 * *$ & 0.055 & 0.016 & $0.392 * *$ \\
\hline & $\mathrm{r}^{\mathrm{g}}$ & $0.793 * *$ & $0.177 *$ & $0.312 * *$ & $-0.174 *$ & $0.498 * *$ & $0.539 * *$ & 0.079 & 0.022 & $0.409 * *$ \\
\hline \multirow[t]{2}{*}{$\mathrm{DM}$} & $\mathrm{r}^{\mathrm{ph}}$ & & 0.107 & $0.310 * *$ & $-0.140 *$ & $0.211^{* *}$ & $0.238^{* *}$ & 0.091 & -0.054 & $0.292 * *$ \\
\hline & $\mathrm{r}^{\mathrm{g}}$ & & 0.109 & $0.341^{* *}$ & $-0.175^{*}$ & $0.248^{* *}$ & $0.277 * *$ & 0.127 & -0.049 & $0.305^{* *}$ \\
\hline \multirow[t]{2}{*}{ PH } & $\mathrm{r}^{\mathrm{ph}}$ & & & $0.484 * *$ & $-0.32 * *$ & $0.470 * *$ & $0.359 * *$ & $0.397 * *$ & -0.099 & $0.422 * *$ \\
\hline & $\mathrm{r}^{\mathrm{g}}$ & & & $0.523 * *$ & $-0.388 * *$ & $0.515^{* *}$ & $0.402 * *$ & $0.508 * *$ & -0.102 & $0.433 * *$ \\
\hline \multirow[t]{2}{*}{ PL } & $\mathrm{r}^{\mathrm{ph}}$ & & & & -0.144 & $0.361 * *$ & $0.344 * *$ & $0.188 *$ & 0.099 & $0.228 * *$ \\
\hline & $\mathrm{r}^{\mathrm{g}}$ & & & & $-0.189 *$ & $0.341^{* *}$ & $0.315^{* *}$ & $0.249 * *$ & 0.107 & $0.254 * *$ \\
\hline \multirow[t]{2}{*}{ ET } & $\mathrm{r}^{\mathrm{ph}}$ & & & & & $-0.211 * *$ & $=0.202 * *$ & 0.107 & 0.114 & -0.036 \\
\hline & $\mathrm{r}^{\mathrm{g}}$ & & & & & $-0.262 * *$ & $-0.251 * *$ & $-0.181 *$ & 0.145 & -0.090 \\
\hline \multirow[t]{2}{*}{ FSP } & $\mathrm{r}^{\mathrm{ph}}$ & & & & & & $0.956 * *$ & $0.307 * *$ & $0.240 * *$ & $0.651 * *$ \\
\hline & $\mathrm{r}^{\mathrm{g}}$ & & & & & & $0.969^{* *}$ & $0.322 * *$ & $-0.259 * *$ & $0.714 * *$ \\
\hline \multirow{2}{*}{$\begin{array}{c}\text { TG } \\
\mathrm{P}\end{array}$} & $\mathrm{r}^{\mathrm{ph}}$ & & & & & & & 0.042 & $-0.167 *$ & $0.579 * *$ \\
\hline & $\mathrm{r}^{\mathrm{g}}$ & & & & & & & 0.089 & $-0.181^{*}$ & $0.642 * *$ \\
\hline \multirow{2}{*}{$\begin{array}{l}\text { SF } \\
\%\end{array}$} & $\mathrm{r}^{\mathrm{ph}}$ & & & & & & & & $-0.267 * *$ & $0.326^{* *}$ \\
\hline & $\mathrm{r}^{\mathrm{g}}$ & & & & & & & & $-0.341 * *$ & $0.422 * *$ \\
\hline \multirow[t]{2}{*}{ TW } & $\mathrm{r}^{\mathrm{ph}}$ & & & & & & & & & $-0.262 * *$ \\
\hline & $\mathrm{r}^{\mathrm{g}}$ & & & & & & & & & $-0.268 * *$ \\
\hline
\end{tabular}

$* \& * *$ : Significant at $5 \%$ and $1 \%$, respectively. 
Table 5: Phenotypic (P) and genotypic (G) matrix of direct and indirect effect on grain yield per plant in sixty upland rice germplasm

\begin{tabular}{cccccccccccc}
\hline Traits & DF & DM & PH & PL & ET & FSP & TGP & SF\% & TW & $\begin{array}{c}\text { Correlation } \\
\text { with GYP }\end{array}$ \\
\hline DF & P & 0.030 & 0.164 & 0.034 & -0.028 & -0.025 & 0.501 & -0.277 & -0.005 & -0.001 & $0.393 * * *$ \\
& G & -0.051 & 0.226 & 0.007 & -0.016 & -0.021 & 1.245 & -0.961 & -0.020 & -0.001 & $0.408^{* *}$ \\
DM & P & 0.024 & 0.204 & 0.021 & -0.031 & -0.025 & 0.240 & -0.139 & -0.008 & 0.005 & $0.291 * *$ \\
& G & -0.040 & 0.285 & 0.004 & -0.018 & -0.021 & 0.619 & -0.494 & -0.031 & 0.001 & $0.305 * *$ \\
PH & P & 0.005 & 0.022 & 0.199 & -0.049 & -0.055 & 0.534 & -0.210 & -0.034 & 0.009 & $0.421 * *$ \\
& G & -0.009 & 0.031 & 0.037 & -0.027 & -0.046 & 1.286 & -0.716 & -0.125 & 0.002 & $0.433^{* *}$ \\
PL & P & 0.008 & 0.063 & 0.097 & -0.100 & -0.025 & 0.411 & -0.201 & -0.016 & -0.009 & $0.228 * *$ \\
& G & -0.016 & 0.097 & 0.019 & -0.051 & -0.023 & 0.852 & -0.561 & -0.061 & -0.002 & $0.254 * *$ \\
ET & P & -0.005 & -0.030 & -0.064 & 0.014 & 0.171 & -0.239 & 0.118 & 0.009 & -0.010 & -0.036 \\
& G & 0.009 & -0.050 & -0.014 & 0.010 & 0.120 & -0.653 & 0.447 & 0.045 & -0.003 & -0.089 \\
FSP & P & 0.013 & 0.043 & 0.094 & -0.036 & -0.036 & 1.137 & -0.558 & -0.026 & 0.021 & $0.652^{* *}$ \\
& G & -0.025 & 0.071 & 0.019 & -0.018 & -0.031 & 2.498 & -1.726 & -0.079 & 0.005 & $0.714 * *$ \\
TGP & P & 0.014 & 0.049 & 0.072 & -0.035 & -0.035 & 1.087 & -0.584 & -0.004 & 0.015 & $0.579 * *$ \\
& G & -0.027 & 0.079 & 0.015 & -0.016 & -0.030 & 2.421 & -1.781 & -0.022 & 0.004 & $0.643 * *$ \\
SF\% & P & 0.002 & 0.019 & 0.079 & -0.019 & -0.018 & 0.349 & -0.024 & -0.085 & 0.024 & $0.327 * *$ \\
& G & -0.004 & 0.036 & 0.019 & -0.013 & -0.022 & 0.804 & -0.159 & -0.246 & 0.007 & $0.422^{* *}$ \\
TW & P & 0.001 & -0.011 & -0.019 & -0.010 & 0.019 & -0.273 & 0.098 & 0.023 & -0.088 & $-0.260^{* *}$ \\
& G & -0.001 & -0.014 & -0.004 & -0.006 & 0.017 & -0.648 & 0.323 & 0.084 & -0.019 & $-0.268^{* *}$ \\
\hline
\end{tabular}

Table 6: Eigen vectors and eigen values of the first four principal components

\begin{tabular}{lcccc}
\hline \multicolumn{1}{c}{ Variable } & PC 1 & PC 2 & PC 3 & PC 4 \\
\hline Days to 50 \% flowering & 0.67 & 0.63 & -0.08 & -0.22 \\
Days to maturity & 0.54 & 0.63 & 0.06 & -0.50 \\
Plant height & 0.65 & -0.37 & 0.46 & 0.13 \\
Panicle length & 0.55 & 0.12 & 0.59 & 0.16 \\
Number of effective tillers per plant & -0.37 & 0.14 & -0.37 & 0.17 \\
Fertile spikelets per panicle & 0.89 & -0.11 & -0.26 & 0.30 \\
Total number of grains per panicle & 0.83 & 0.06 & -0.31 & 0.40 \\
Spikelet fertility percentage & 0.44 & -0.54 & 0.20 & -0.42 \\
Test weight & -0.27 & 0.50 & 0.46 & 0.50 \\
Grain yield per plant & 0.77 & -0.14 & -0.29 & 0.05 \\
Eigen Value & 3.92 & 1.54 & 1.21 & 1.041 \\
Variance (\%) & 39.20 & 15.41 & 12.11 & 10.41 \\
Cumulative variance (\%) & 39.20 & 54.61 & 66.72 & 77.13 \\
\hline
\end{tabular}

